\title{
Can We Grow Shallot (Allium ascalonicum L.) Root in Hydroponic System with Simple Growing Media?
}

\author{
Trio Fanny1, Eliyani1 ${ }^{1}$ Odit Ferry Kurniadinata*1 \\ ${ }^{1}$ Faculty of Agriculture, Universitas Mulawarman, Samarinda, East Kalimantan Province, Indonesia \\ *Corresponding author: odit.ferry@faperta.unmul.ac.id
}

\section{ARTICLE HISTORY}

$\begin{array}{ll}\text { Received } & : 3 \text { July } 2020 \\ \text { Revised } & : 12 \text { August } 2020 \\ \text { Accepted } & : 14 \text { September } 2020\end{array}$

\section{KEYWORDS}

Bulbs;

Egg Cartons;

Burnt Rice Husk;

Wood Shavings;

Root Performance;

\begin{abstract}
Unlike conventional agriculture, urban hydroponics are widely on a small yard scale. Hydroponics is a term used for farming without using soil as a growth medium. Plants can be planted in pots or other containers using water and other porous materials as growing media. Cheap, easily obtainable, and efficient growing media types are needed for urban communities to cultivate vegetable crops, especially shallots (Allium ascalonicum L.). Shallots have an important meaning, both in terms of high economic value and their nutritional content. It is unknown if the shallots are cultivated in a hydroponic system and how the performance of its roots and the suitable simple growing media for growing shallots in hydroponic will be enhanced. Therefore, this research was conducted to study the performance of shallot roots in several alternative hydroponic media and obtain growing media that can provide the best growth on the performance of shallot roots in the hydroponic system. The experiment was conducted in 3 months at the Glass House and Integrated laboratory of the Faculty of Agriculture, Mulawarman University, Indonesia. This research was arranged in a Randomized Block Design (RBD) with four replications. The factor is the growing media $(\mathrm{m})$ which consists of 4 levels, namely: $\mathrm{m} 1=$ sand ( \pm 80-100 mesh); $\mathrm{m} 2$ = burnt rice husk; $\mathrm{m} 3=$ egg cartons; and $\mathrm{m} 4=$ wood shavings $( \pm 90-120$ mesh). Data retrieval by observing the following parameters: Leaf length (cm), Number of leaves (strands), Number of plant bulbs (bulbs), bulbs wet weight (grams), bulbs dry weight (grams), Longest root length $(\mathrm{cm})$, and Total root length $(\mathrm{m})$. This research showed that the burnt rice husk and wood shavings growing media influence the growth and performance of the shallots' roots (Allium ascalonicum L.) plants and can be used as the simple growing media in urban hydroponic as Household scale cultivation. On the other hand, the growing media from sand and egg cartons are not recommended for growing shallots in the hydroponic system.
\end{abstract}

This is an open-access article under the CC-BY-SA license.

\section{INTRODUCTION}

Shallots are vegetables that have an important meaning, both in terms of high economic value and nutritional content. In the last decade, the demand for shallots for consumption and seeds has increased. Shallots require fertile land with a growing media condition that is porous, loose, and not flooded. According to Samanhudi \& Harjoko (2006), the development of the industry is increasingly advanced. The development will rapidly replace agricultural lands, especially in big cities; as a result, agricultural land will be increasing rapidly. However, on the other hand, the need for agricultural products increases with the increasing people population.

One of the goals of agricultural development is to improve farmers' welfare by increasing farm income, especially in vegetable crops, by changing farmers' mindset, knowledge, and skills in cultivating horticultural crops on vegetable crops in a more efficient and competitive direction. Currently, a healthy lifestyle that is familiar with the environment has become a new trend of starting a new lifestyle by using vegetables that are planted on a household scale because they are considered safe for consumption. Household-scale crop cultivation is carried out by utilizing the remaining yard conditions to meet family needs. Conventional agriculture is generally on a medium or large scale, and the product is sold. Unlike conventional agriculture, urban hydroponics is widely practiced on a household scale. This goal is to meet the needs of vegetables and fruits for their own families and surrounding communities. Hydroponics is a 
term used for farming without using soil as a growth medium. Plants can be planted in pots or other containers by using water and other porous materials such as gravel, roof tiles, sand, wood shavings, and other media as growing media.

Hydroponics emerged as an alternative to limited land agriculture. This system allows vegetables to be planted in small areas that are densely populated. Plants will grow well if the nutrients needed are met and easily absorbed through the roots. The root can grow and penetrate the media and achieve the nutrients supplied to the hydroponic system is strongly influenced by the type and condition of the given growing media. If the growing media is in accordance with what is desired by the plant, the roots can function normally. Cheap, easily obtainable, and efficient types of growing media are needed for urban communities to cultivate vegetable crops, especially shallots. Shallots have a root system in the form of root fibers that are not too long and not deep, embedded in the soil (Wibowo, 2001). It only develops at a depth of about $30 \mathrm{~cm}$ from the ground. A number of adventive roots with a diameter of $\pm 1.5 \mathrm{~mm}$ grow from the stem. The amount of shallots root is very limited. Root formation occurs continuously along with plant growth. It is unknown if the shallots are cultivated in a hydroponic system and how the performance of its roots and the simple growing media for the urban condition is suitable for hydroponic shallots cultivation. Therefore, this research was conducted to study the performance of shallot roots in several alternative hydroponic media and obtain growing media that can provide the best growth on the performance of shallots roots in the hydroponic system.

\section{MATERIALS AND METHODS}

This research has been carried out for three months and is located in the Glass House and Integrated laboratory of the Faculty of Agriculture, Mulawarman University, Indonesia. The materials used in this study were bulbs from shallots var. Bauji, sand, burnt rice husk, egg cartons, wood shavings, $\mathrm{AB}$ Mix nutrition, and water. This research was arranged in a Randomized Block Design (RBD) with four replications. The factor is the growing media (m) which consists of 4 levels, namely: $\mathrm{m} 1=$ sand ( \pm 80-100 mesh); $\mathrm{m} 2$ = burnt rice husk; $\mathrm{m} 3$ = egg cartons; and $\mathrm{m} 4=$ wood shavings ( \pm 90-120 mesh). Data retrieval by observing the following parameters: Leaf length $(\mathrm{cm})$, Number of leaves (strands), Number of plant bulbs (bulbs), bulbs wet weight (grams), bulbs dry weight (grams), Longest root length $(\mathrm{cm})$, and Total root length $(\mathrm{m})$. Root calculation is done by cutting the shallots root, which is then spread on the Grid Unit. The calculation can be done by calculating the spread of roots affected by vertical and horizontal lines (Tennant,1975). $\mathrm{R}=11 / 14 \times$ Number of Intercepts (N) x Grid Unit.

Where:

Grid Unit $=1 \mathrm{~cm}(0,7857)$

$\mathrm{N}=$ Number of Intercepts

$\mathrm{R}=$ Total root length

\section{RESULTS AND DISCUSSIONS}

\subsection{Leaf Length and Number of Leaves in Different Growing Media}

The results showed that the highest leaf length and number of leaves were obtained from burnt rice husk media, while the lowest leaf length was obtained from egg cartons media (Table 1). Viewed from the type of growing media, there are differences in each media's physical properties. On the egg cartons media, density occurs, resulting in air and water circulation not going well. Shallots plants do not prefer humid and wet conditions. Whereas the burnt rice husk media has better properties because the burnt rice husk easily binds water, the level of porosity is right and can store nutrients, so it is good for the early growth of generative phase plants.

Table 1. Leaf length and number of leaves in different growing media

\begin{tabular}{llllllllllll}
\hline \multirow{2}{*}{ Growing Media } & \multicolumn{10}{c}{ Observation } \\
\cline { 2 - 12 } & \multicolumn{1}{c}{ Leaf Length (cm) } \\
\cline { 2 - 12 } & $10.93 \mathrm{ab}$ & $20.66 \mathrm{a}$ & $20.46 \mathrm{a}$ & $20.89 \mathrm{a}$ & $20.14 \mathrm{~b}$ & 11.13 & $17.69 \mathrm{~b}$ & $17.63 \mathrm{~b}$ & $12.25 \mathrm{a}$ & $12.69 \mathrm{a}$ \\
\hline Sand & $11.96 \mathrm{~b}$ & $29.54 \mathrm{~b}$ & $30.15 \mathrm{~b}$ & $39.11 \mathrm{~b}$ & $42.60 \mathrm{c}$ & 10.81 & $23.31 \mathrm{c}$ & $23.56 \mathrm{c}$ & $38.88 \mathrm{~b}$ & $39.25 \mathrm{~b}$ \\
Burnt rice husk & $9.12 \mathrm{a}$ & $18.93 \mathrm{a}$ & $17.36 \mathrm{~b}$ & $16.73 \mathrm{a}$ & $16.28 \mathrm{a}$ & 9.69 & $12.75 \mathrm{a}$ & $13.13 \mathrm{a}$ & $9.32 \mathrm{a}$ & $9.69 \mathrm{a}$ \\
Egg cartons & $8.83 \mathrm{a}$ & $27.83 \mathrm{~b}$ & $27.66 \mathrm{~b}$ & 40.59 & $41.07 \mathrm{c}$ & 10.5 & $23.69 \mathrm{c}$ & $23.75 \mathrm{~b}$ & $39.75 \mathrm{~b}$ & $35.06 \mathrm{~b}$ \\
Wood shavings & $*$ & $* *$ & $* *$ & $* *$ & $* *$ & ns & $* *$ & $* *$ & $* *$ & $* *$
\end{tabular}

The numbers followed by the same letters in the yellow gum score column show no significant difference as determined by $5 \%$ DMRT test.

Growth of shallot leaves will decrease with increasing plant age. This also happened in a study conducted by
Fauziah, et al., (2016). Older shallots plants will reduce its vegetative growth. Entering five Weeks After Planting 
(WAP), shallot plants will use photosynthesis to form and enlarge the bulbs. Based on observations, at the age of 14 day after planting (DAP) to 21 DAP, shallots planted in sand and egg cartons media had a generative growth phase earlier than other media. This is because the plants try to meet the nutrient needs to support their growth (vegetative phase), which are not supported by appropriate growing media. In other words, plants are stress by planting in sand and egg cartons media to grow and develop at the beginning of plant growth.

\subsection{Number of Bulbs, Wet Weight of Bulbs, Dry Weight of Bulbs, Root Length, and Total Root Length in Different Growing Media}

The highest number of bulbs was obtained from the treatment of growing media from burn husk, which was 12.81 bulbs, while the lowest number of bulbs were found from egg cartons media, as much as 6.38 bulbs (Table 2). The observations showed at the 14 DAP until 21 DAP, the plants in sand and egg cartons showed earlier bulbs formation compared to the burnt rice husk growing media and wood shavings. This is thought due to the growing media's inappropriate conditions causing the vegetative phase to cease and proceed to the earlier generative phase. Sand media have high water-saving properties but are difficult to circulate. In egg cartons media, the lowest number of bulbs produced from another treatment media was due to the egg cartons media storing water excessively. The egg cartons media became saturated and dense, and shallots bulbs cannot grow optimal. The small number of leaves and leaf surface area caused the photosynthetic processes to be suboptimal, and photosynthates in bulbs are also low.

The media of sand and egg cartons can store large amounts of water, which is not good as a place to grow shallots bulbs because the media is continuously wet, so it cannot support plants' growth, including producing many bulbs. This study indicates that the use of burnt husk media and wood shavings is appropriate in the hydroponic, especially for shallots plants. Because the shallots plant requires growing media that is not too dense. This is intended because when entering the generative phase, the shallots will form new bulbs and they require a growing medium that is not too dense.

Table 2. Number of bulbs, wet weight of bulbs, dry weight of bulbs, root length and total root length in different growing media

\begin{tabular}{lccccc}
\hline & \multicolumn{5}{c}{ Observation } \\
\cline { 2 - 6 } Growing Media & Number of bulbs & $\begin{array}{c}\text { Fresh weight of } \\
\text { bulbs }\end{array}$ & $\begin{array}{c}\text { Dry weight of } \\
\text { bulbs }\end{array}$ & root Length & total root length \\
\cline { 2 - 6 } Sand & $7.5 \mathrm{ga}$ & $12.33 \mathrm{~b}$ & $7.94 \mathrm{a}$ & $9.20 \mathrm{a}$ & $1.80 \mathrm{a}$ \\
Burnt rice husk & $12.81 \mathrm{~b}$ & $58.77 \mathrm{~b}$ & $43.36 \mathrm{~b}$ & $31.03 \mathrm{c}$ & $7.12 \mathrm{~b}$ \\
Egg cartons & $6.38 \mathrm{a}$ & $8,57 \mathrm{a}$ & $6.01 \mathrm{a}$ & $17.07 \mathrm{ab}$ & $2.75 \mathrm{a}$ \\
Wood shavings & $11.75 \mathrm{~b}$ & $57.46 \mathrm{~b}$ & $37.18 \mathrm{~b}$ & $32.02 \mathrm{bc}$ & $5.91 \mathrm{~b}$ \\
\hline Sig. & $* *$ & $* *$ & $* *$ & $* *$ & $*$
\end{tabular}

The numbers followed by the same letters in the yellow gum score column show no significant difference as determined by $5 \%$ DMRT test

The results showed that the highest wet and dry weight of bulbs were found in burnt husk media, while the lowest fresh and dry weight of bulbs were found in egg cartons media (Table 2). This is influenced by several aspects, including leaf length and number of leaves, and plants' root performance. Besides, the availability of water and mineral nutrients in the planting medium affects the bulbs' weight. The wet weight is influenced by the water content and nutrient content in plant tissue cells (Rahayu, et al., 2008; Mas'ud, 2009). Another study conducted by Gustia (2013) showed that burnt rice husk media also produced the highest fresh bulbs weight.

Based on the observations showing that the use of burnt rice husk media is suitable for bulbs growth in hydroponic cultivation. According to Hamli, et al. (2015), shallot plants' growth requires porous media for bulbs formation and growth. Porous growing media will be easily penetrated by roots so that the bulbs formed are larger and more numerous (Elisabeth et al., 2013). Burnt rice husk also has properties that cannot be rotten, not clot or condense so that plant roots can grow correctly (Rahayu, et al., 2013). The fresh and dry bulbs weight indicates plant's ability to absorb nutrients and accumulate them as a reserve of energy sources. The dry weight reflects the accumulation of organic compounds that have been successfully synthesized by plants. This nutrient absorption is closely related to plant roots' growth (Jasmi, et al., 2013; Marta, et al., 2020; Margiwiyanto, et al., 2011; Lonardy, 2006). 

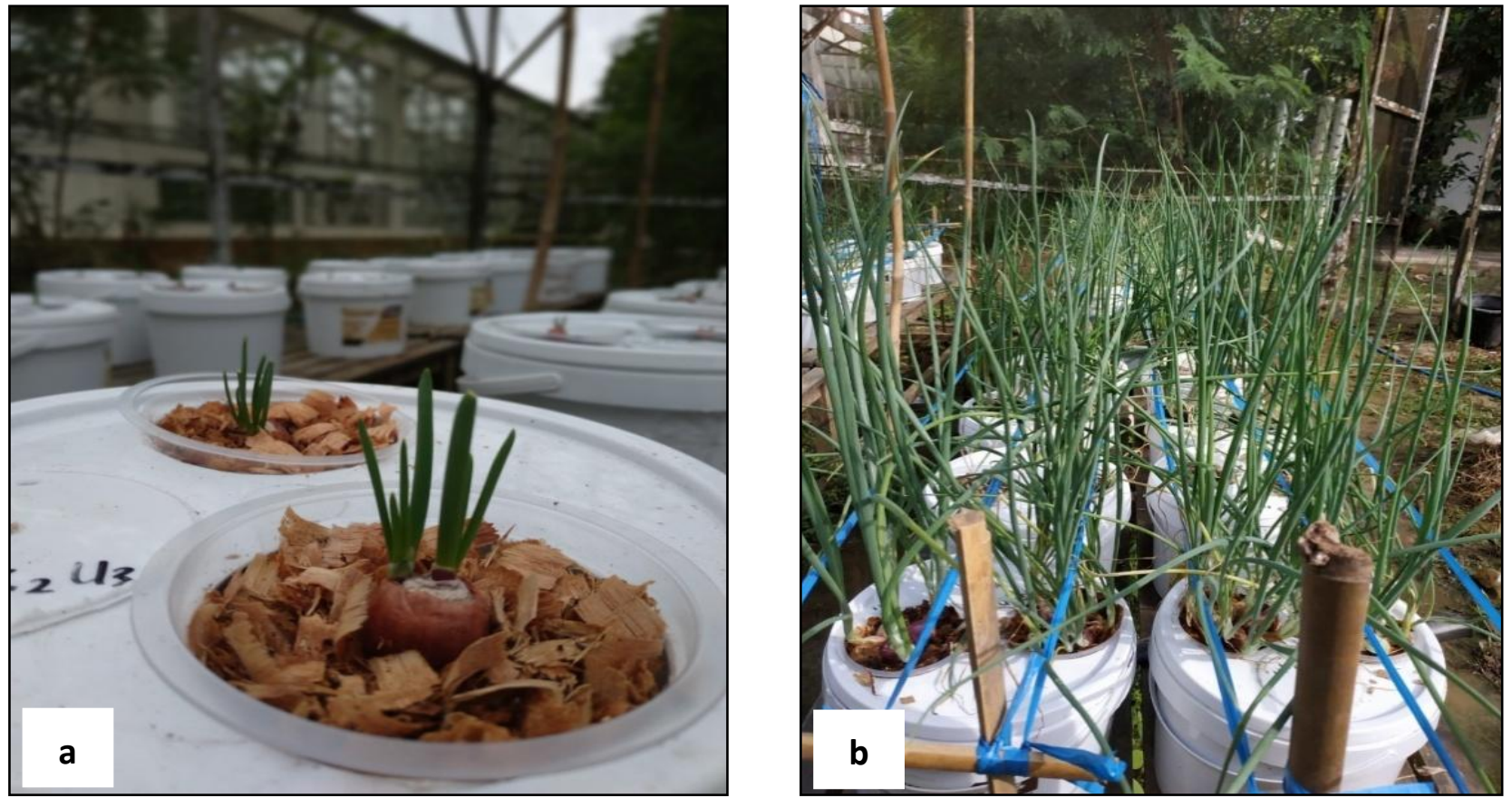

Figure 1. Shallot bulbs planted in growing media: a) in wood shaving, b) in rows

If the roots are good, it will produce more photosynthate, then the dry weight of plants will increase. The fresh weight is directly proportional to the dry weight of bulbs (Putrasamedia, 2007; Marpaung, et al., 2019). If the bulbs' fresh weight has high, the bulbs' dry weight will high as well. Drying is to obtain the value of water content sufficient for the storage of bulbs. Drying under the sun is one of the bulbs drying techniques. With this technique, the water content of shallots bulbs will around $65-75 \%$ (Astuti, 2008). Another reason that influences the size of the shallots' fresh and dry weight is the growing media characteristic because besides being a place to support growth, it also basically be a place for roots to develop. The root also has a function to find and get nutrients for plants in the growing medium. The roots will absorb the nutrients needed for plants. At the tip of the root there are living cells called a root cap (calyptra) to penetrate the soil or growing media. If the growing media used are not suitable for root plants to grow, the roots will be difficult to penetrate and develop, and then it can affect the function of the roots. As a result, the roots do not optimally supply nutrients and cannot support plants' growth (Hamdani, 2008; Indrawati, et al., 2012; Wahyuningsih, et al., 2017).
Shallot roots are easy to grow in the appropriate growing media. If the growing media is not supportive, then the shallots root is difficult to carry out its normal activities. If the roots are in an undesirable environment, the plant can inhibit its growth. In the growing media of sand and egg cartons, shallot plants cannot grow and develop properly. This is because, in the sand media, roots cannot penetrate the planting medium to the maximum. As a result, the roots of plants have difficulty in finding nutrients needed by plants, and also sand media has a character easy to absorb water, and it makes the media-saturated and dense, so the ability of roots to penetrate the growing media is difficult. On the egg carton media, the root is prone to decay; this is because the egg carton media is easy to absorb and store water, so the egg carton media becomes excessively moist and is not preferred in shallots' roots plants. Another reason the egg cartons not suitable for shallots cultivation in hydroponic is it becomes compact, and make the shallots roots are difficult to spread. Then roots become damage and get rotten. Root damage due to root can penetrate well to growing media and cause absorption of nutrients disturbed and result plant getting weak and death. 

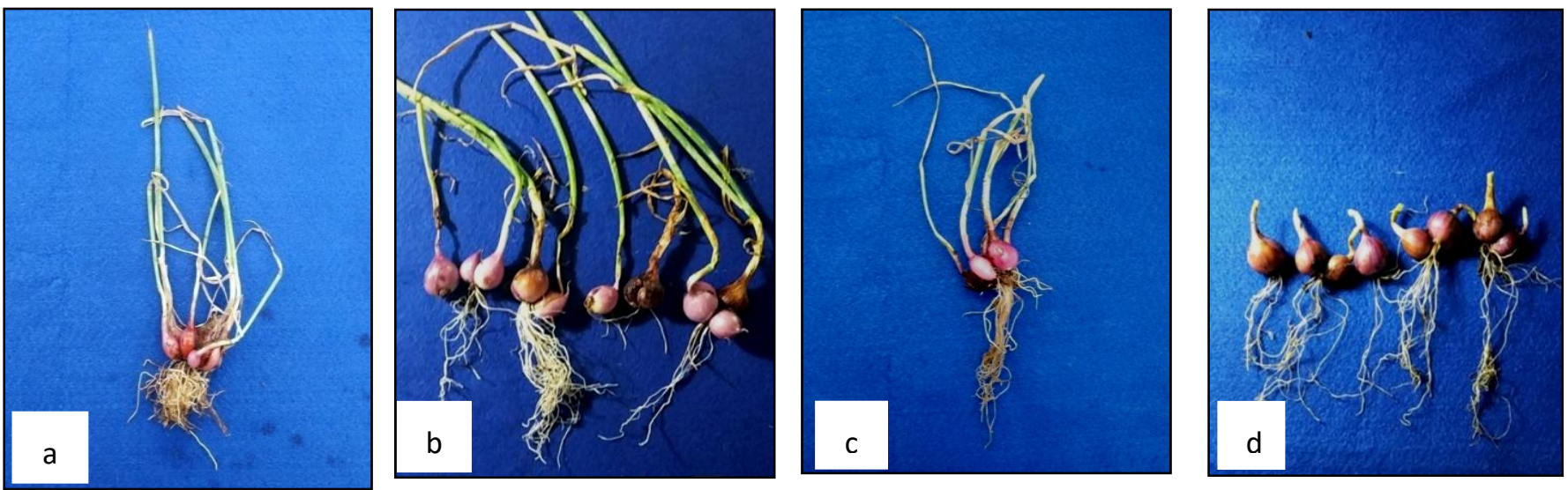

Figure 2. Number of bulbs and plant root condition in the sand (a), burnt rice husk (b), wood shaving (c), and growing media (d)

Burnt rice husk and wood shavings media are the best media compared to the two media above. Burnt rice husk media has a good porosity level as well as wood shavings media. This is useful in root growth because the roots need a place that is not too dense and moist as in the sand and egg cartons media. Another advantage of burnt rice husk and wood shavings media is this media makes it easier for roots to penetrate and develop. This can be seen from the roots perform. The most extended root length indicates that the root can grow and develop in the desired planting medium. The most extended root length can also affect roots' performance in supplying plants' needs, both vegetative and generative in phase. The longer the root, the greater the dry weight (Sofyan et al., 2014). The growth of root and stem organs is very complex, especially in photosynthate mobilization; many factors affect plants. If conditions are limited, root growth will be encouraged to get more nutrients and water (Siswadi, 2015). The root system's development would influence seedling canopy, namely the height and diameter of seedlings. The root provides nutrients and water needed for photosynthesis, while the canopy provides the photosynthate needed for the growth of roots and other parts.

Based on this study's results, it was found that the burnt rice husk media was the best compared to other media. Burnt rice husk media has better properties because it easily binds water. It has a good level of porosity and can store nutrients from the fertilizer, so it is good for all vegetative and generative stage plants' initial growth. Other best media is wood shavings media, it can be seen from the parameters observed either leaf length, number of leaves, number of bulbs, fresh weight bulbs, dry weight bulbs, root length, and total root length. This is because the wood shavings media has a cavity between the growing media, which benefits in spreading plant roots and bulbs formation from the shallots plant.

Inadequate growing media on hydroponic systems for shallots is sand and egg cartons media. This is because the media have the ability to store large amounts of water, which is not as good as a place for shallots plant development. After all, the media is constantly fresh, so it has not been able

to produce growth and better results. Shallots are planted in a suitable environment; then there will be a good interaction between genetic factors with environmental factors (Azmi, et al., 2011).

Based on this study's results, the growing media of sand and egg cartons are not recommended for growing shallots in the hydroponic system. Widodo (1996) states that plant roots will develop well if supported by sufficient water, nutrients, and air from the growing media. If the growing media is not in accordance with what the plants want, then the roots are difficult to move. Growing media is an important external factor because it has many functions, as a place for plants to stand upright and a place for roots to move and grow. Egg cartons media has properties that easily absorb excess water so that the media becomes saturated and solid. This trait is a weakness in the performance of roots to carry out their normal activities because plant roots cannot develop and penetrate the planting medium. The fresh weight on the Egg cartons media also shows a low number is directly proportional to bulbs consumption's dry weight. This is an indication that the growth media factor affects plant roots, which can reduce yield.

Roots on the sand growing media also showed the shallots not growing well. The total root and the most extended root length in sand media have the lowest value than burnt rice husk and wood shavings media. This is because the stress condition due to the growing media condition can indicate that root development is inhibited. Density is one of the physical obstacles for root growth. The effect of density on the growing media can interfere and inhibit the formation of plant roots. Materechera, et al., (1992) states that in dense land (hardpan), plant roots usually grow thicker. While other opinions are explained by Duruoha, et al., (2007) in their research that in soils condition are dense, the rate of root elongation will slow down, and growth is stopped. The density that occurs in the sand media also becomes a reason for the development of roots. The characteristic of sand in 
absorbing water causes the growing media to become dense and fresh so that plants are difficult to develop, both in developing bulbs and plant roots. That factor, which is a sand planting medium, is rarely used in hydroponic systems.

\section{CONCLUSIONS}

The burnt rice husk growing media and, following by wood shavings media, provide the best influence on the growth and performance of the shallots plants' roots. These can be used as the simple growing media in urban hydroponic as Household scale cultivation.

\section{REFERENCES}

Astuti, S. M. (2008). Teknik pengeringan bawang merah dengan cara perlakuan suhu dan tekanan vakum. Buletin Teknik Pertanian, 13(2), 79-82.

Azmi, C., Hidayat, I. M., \& Wiguna, G. (2016). Pengaruh varietas dan ukuran umbi terhadap produktivitas bawang merah. Jurnal Hortikultura, 21(3), 206-213.

Duruoha, C., Piffer, C. R., \& Silva, P. A. (2007). Corn root length density and root diameter as affected by soil compaction and soil water content. Irriga, 12(1), 14-26.

Elisabeth, D. W., Santoso, M., \& Herlina, N. (2013). Pengaruh pemberian berbagai komposisi bahan organik pada pertumbuhan dan hasil tanaman bawang merah (Allium ascalonicum L.). Jurnal Produksi Tanaman, 1(3).

Fauziah, R., Susila, A. D., \& Sulistyono, E. (2016). Budidaya bawang merah (Allium ascalonicum L.) pada lahan kering menggunakan irigasi sprinkler pada berbagai volume dan frekuensi. Jurnal Hortikultura Indonesia, 7(1), 1-8.

Gustia, H. (2013). Pengaruh penambahan Sekam Bakar Pada Media Tanam Terhadap Pertumbuhan Dan Produksi Tanaman Sawi (Brassica juncea L.). E-Journal Widya Kesehatan dan Lingkungan, 1(1).

Hamdani, L. S. (2008). Pertumbuhan dan Hasil Bawang Merah Kultivar Kuning pada Status Hara P Total Tanah dan Dosis Pupuk Fospat yang Berbeda. Agrikultura, 19(1).

Hamli, F., Iskandar, M. L., \& Ramal, Y. (2015). Respon pertumbuhan tanaman sawi (Brassica juncea L.) secara hidroponik terhadap komposisi media tanam dan konsentrasi pupuk organik cair. Jurnal Agrotekbis, 3(3), 290-296.

Indrawati, R., Indradewa, D., \& Utami, S. N. H. (2012). Pengaruh komposisi media dan kadar nutrisi hidroponik terhadap pertumbuhan dan hasil tomat (Lycopersicon esculentum Mill.). Vegetalika, 1(3), 109-119.

Jasmi, E. S., \& Indradewa, D. (2013). pengaruh vernalisasi umbi terhadap pertumbuhan, hasil, dan pembungaan bawang merah (Allium Cepa L. Aggregatum Group) di dataran rendah. Ilmu Pertanian (Agricultural Science), 16(1), 42-57.

Lonardy, M. V. (2006). Respons tanaman tomat (Lycopersicon esculentum mill.) terhadap suplai senyawa nitrogen dari sumber berbeda pada sistem hidroponik. Skripsi"(Tidak Dipublikasikan). Universitas Tadulako, Palu.

Margiwiyatno, A., \& Sumarni, E. (2014). Modifikasi iklim mikro pada bawang merah hidroponik dalam rangka memperoleh bibit bermutu. Jurnal Keteknikan Pertanian, 25(1).

Marpaung, A. E., \& Rosliani, R. (2019). Adaptability of Growth and Yield on 5 varieties of Shallot (Allium ascalonicum L) in Wet Highland. Journal of Tropical Horticulture, 2(1), 1-5.

Marta, N., Kuswandi, K., Andini, M., Sunyoto, S., Irawati, Y., Nofiarli, N., \& Nasution, F. (2020). The Effect of the Medium and the Variety on the Yield of Shallots (Allium ascalonicum L.) Grown in a Polybag. Journal of Tropical Horticulture, 3(1), 19-22.

Mas' ud, H. (2009). Sistem hidroponik dengan nutrisi dan media tanam berbeda terhadap pertumbuhan dan hasil selada. Media Litbang Sulteng, 2(2).

Materechera, S. A., Alston, A. M., Kirby, J. M., \& Dexter, A. R. (1992). Influence of root diameter on the penetration of seminal roots into a compacted subsoil. Plant and soil, 144(2), 297-303.

Askari-Khorasgani, O., \& Pessarakli, M. (2019). Agricultural management and environmental requirements for production of true shallot seeds-a review.

Putrasamedja, S. (2007). Pengaruh berbagai macam bobot umbi bibit bawang merah (Allium ascalonicum L.) yang berasal dari generasi ke satu terhadap produksi. Agrin, 11(1).

Rahayu, M., Samanhudi, S., \& Widodo, A. S. (2013). Pengaruh Macam Media dan Konsentrasi Pupuk Fermentasi Ampas Tahu terhadap Pertumbuhan dan Hasil Tanaman Seledri (Apium Graveolens L.) secara Hidroponik. Sains Tanah-Journal of Soil Science and Agroclimatology, 5(2), 75-82.

Samanhudi \& Harjoko, D. (2006). Pengaturan Komposisi Nutrisi dan Media dalam Budidaya Tanaman Tomat dengan Sistem Hidroponik. UNS Surakarta.

Siswadi, Y. T. (2015). Pengaruh macam media terhadap pertumbuhan dan hasil selada (Lactuca sativa L.) hidroponik. Jurnal Agronomika, 9(3), 257-264.

Sofyan, S. E., Riniarti, M. \& Duryat (2014). Pemanfaatan Limbah Teh, Sekam Padi, Dan Arang Sekam Sebagai Media Tumbuh Bibit Trembesi (Samanea Saman). Jurnal Sylva Lestari, 2(2), 61-70.

Tennant, D. (1975). A test of a modified line intersect method of estimating root length. The Journal of Ecology, 995-1001.

Wahyuningsih, A., Fajriani, S., \& Aini, N. (2017). Komposisi nutrisi dan media tanam terhadap pertumbuhan dan hasil tanaman pakcoy (Brassica rapa L.) sistem hidroponik. Jurnal Produksi Tanaman, 4(8).

Wibowo, S. (2008). Budidaya bawang putih, merah dan bombay. Penebar Swadaya. Jakarta.

Widodo, W. D. (1996). Memperpanjang Umur Produktif Cabai. Surabaya: Trubus Agrisarana. 